\section{Sensitivity of Elevated C-Reactive Protein serum levels in Diagnosis of Chorioamnionitis among pregnant women with gestational diabetes}

Aleksandra Tubic ${ }^{1}$, Marijana Sasic ${ }^{2}$, Aleksandra Simic ${ }^{3}$, Dragana Radovic Janosevic ${ }^{1}$

${ }^{1}$ Clinic for Gynecology and Obstetrics, Clinical Centre Nis, Nis, Serbia

${ }^{2}$ The Railway Health Care Institute, Belgrade, Serbia

${ }^{3}$ Hospital for Gynecology and Obstetrics, Clinical Hospital Center

„Zemun“, Belgrade, Serbia

\section{Senzitivnost povišenog \\ C-reaktivnog proteina u dijagnostici horioamnionitisa kod trudnica sa gestacionim dijabetesom}

\author{
Aleksandra Tubić ${ }^{1}$, Marijana Šašić ${ }^{2}$, Aleksandra Simić ${ }^{3}$, \\ Dragana Radović Janošević ${ }^{1}$ \\ ${ }^{1}$ Klinika za ginekologiju i akušerstvo, Klinički centar Niš, Niš, Srbija \\ ${ }^{2}$ Institut za zdravstvenu zaštitu železnice, Beograd, Srbija \\ ${ }^{3}$ Bolnica za ginekologiju i akušerstvo, Kliničko-bolnički centar \\ „Zemun”, Beograd, Srbija
}

\section{Abstract}

The role of elevated C-Reactive Protein (CRP) serum levels has been questioned in gestational diabetes mellitus (GDM) because of the evidences that metabolic syndrome and GDM are related to increased serum levels of inflammation markers (such as CRP).

The aim of the study was to evaluate the sensitivity of elevated CRP levels for diagnosis of chorioamnionitis and to compare it with sensitivity of other standard laboratory or clinical signs used in the establishing of diagnosis of chorioamnionitis.

Elevated CRP level was present in $93,33 \%$ cases. Fetal tachycardia was present in $91,67 \%$ cases. Increased white blood cell count was present in $63,33 \%$. A statistically significant difference was found in the level of sensitivity of CRP and of the increased white blood cell count $(\mathrm{P}<0.01)$. Elevated $\mathrm{C}$-reactive protein levels were more sensitive than other standard laboratory or clinical signs in predicting chorioamnionitis in women with GDM.

Keywords: Chorioamnionitis, Gestational Diabetes, C-reactive protein, Sensitivity

\section{Apstrakt}

Uloga povišenog serumskog C-Reaktivnog Proteina (CRP) u dijagnostici horioamnionitisa dovodi se u pitanje kod gestacijskog dijabetesa (GDM) zbog povezanosti metaboličkog sindroma i GDM-a sa visokim serumskim nivoima markera inflamacije (kao što je CRP).

Cilj studije je da evaluira senzitivnost povišenog CRP-a u dijagnostici horioamnionitisa u GDM pacijenata i uporedi je sa senzitivnošću ostalih laboratorijskih parametara i kliničkih znakova koji se koriste u dijagnostici ovog entiteta.

Povišen CRP bio je prisutan u 93,33\% slučajeva horioamnionitisa, fetalna tahikardija u 91,67\%, leukocitoza u 63,33\% slučajeva. Pronađena je značajna razlika u nivou senzitivnosti CRP-a i leukocitoze $(\mathrm{P}<0.01)$. Povišen CRP je osetljiviji $\mathrm{u}$ odnosu na druge parametre $\mathrm{u}$ detekciji horioamnionitisa kod trudnica sa GDM-om.

Ključne reči: Horioamnionitis, Gestacioni Dijabetes, C-reaktivni protein, Senzitivnost

\title{
Introduction
}

Chorioamnionitis has an effect on numerous pregnancies complicated by preterm premature rupture of membranes1. Finding a serum factor that could truthfully envisage the presence of chorioamnionitis could potentially direct to more efficient management of preterm premature rupture of membranes. Numerous studies have supported the use of CRP in diagnosing chorioamnionitis ${ }^{1,2}$. However, this role could be questioned in gestational diabetes mellitus (GDM) because an expanding body of evidence has linked the metabolic syndrome and GDM with several emerging non-traditional risk factors, including markers of inflammation, such as $\mathrm{CRP}^{3,4}$. However, other authors found disagreeing evidences. They found no correlation between CRP serum levels and GDM and they reported lack of predictive value of CRP in GDM ${ }^{5}$. 
The aim of this study was to evaluate the sensitivity of elevated C-reactive protein (CRP) levels in detection of chorioamnionitis and to comare it with sensitivity of other laboratory or clinical sings which are in use for establishing the diagnosis of chorioamnionitis.

\section{Materials and Methods}

The retrospected study entailed the evaluation of medical records of 60 pregnant woman with GDM, who were in a tertiary health center diagnosed with chorioamnionitis as well. Diagnosis was established by the presence of at least two of the following laboratory or clinical signs in predicting chorioamnionitis ${ }^{2}$ : increased white blood cell count, fever, maternal tachycardia, fetal tachycardia, malodorous amniotic fluid, malodorous discharge from uterine cervix, uterine tenderness, elevated CRP serum levels.

Data is expressed as mean values with standard deviation for skewed data. Categorical data is presented in absolute numbers with percentages and analysed using chi-square test and Fisher's exact test. For continuous variables, Student's $t$-test was used. A P value of $<0.05$ was considered statistically significant. The diagnostic value of each laboratory or clinical sign used for the diagnosis of chorioamnionitis were evaluated for sensitivity (Sn).

\section{Results}

The mean maternal age \pm SD was $25.96 \pm 6.40$ years. Forty-nine women $(80 \%)$ were nulliparous and 12 $(20 \%)$ were multiparous women. The mean gestational age at the moment of the diagnosis of chorioamnionitis $\pm \mathrm{SD}$ was $33.17 \pm 1.42$ weeks.

Diagnostic characteristics of laboratory or clinical signs of the chorioamnionitis evaluated by sensitivity are summarized in Table 1.

\begin{tabular}{|l|l|l|}
\hline & Number of patients & Sensitivity \\
\hline Elevated serum CRP level & 56 & $93,33 \%$ \\
\hline Fever & 55 & $91,67 \%$ \\
\hline Fetal tachycardia & 55 & $91,67 \%$ \\
\hline Maternal tachycardia & 42 & $70 \%$ \\
\hline Increased white blood cell count & 38 & $63,33 \%$ \\
\hline Malodorous amniotic fluid & 21 & $35 \%$ \\
\hline Malodorous discharge from uterine cervix & 19 & $31.67 \%$ \\
\hline Uterine tenderness & 14 & $23.33 \%$ \\
\hline
\end{tabular}

Table 1. Diagnostic characteristics of laboratory or clinical signs of the chorioamnionitis evaluated by sensitivity

A highly statistically significant difference was between the levels of sensitivity of CRP, fever and fetal tachycardia comparing with the sensitivity levels of increased white blood cell count, uterine tenderness, malodorous amniotic fluid and discharge from uterine cervix $(\mathrm{P}<0.01)$. The difference between sensitivity of maternal tachycardia and the sensitivity of the most efficient sings of chorioamnionitis (elevated serum CRP levels, fever and fetal tachycardia) was significant $(\mathrm{P}<0.01)$.

\section{Conclusion}

The present study dealed with diagnostic value of laboratory or clinical signs of chorioamnionitis in GDM evaluated by the sensitivity of each sign. Our study results confirmed that elevated C-reactive protein levels were more sensitive than other standard laboratory or clinical tests in predicting chorioamnionitis in women with GDM. This is in accordance with the finding of other studies regarding general population ${ }^{3}$ of pregnant 
women or pregnant women with $\mathrm{GDM}^{4}$. In addition, in a cross-sectional study which examined the role of CRP in the association between BMI and GDM, CRP has emerged as the most important determinant of chorioamnionitis, independent of $\mathrm{GDM}^{6}$.

However, the relationship between perinatal inflamation, gestational diabetes, chorioamnionitis are incompletely understood ${ }^{7}$. Our results could be of the importance in the light of the fact that chorioamnionitis is often asymptomatic and clinical signs such as uterine tenderness and malodorous amniotic fluid or cervical discharge lack both sensitivity and specificity. Furtermore, chorioamnionitis occurs without microbiologicalyproven amniotic fluid infection in over half of cases, due to fastidious organisms, sampling limitations and prior exposure to antibiotics ${ }^{8}$. Also, recent reports indicate that serial CRP levels during this interval may be useful for monitoring of antibiotic treatment ${ }^{8}$.

\section{Literature}

1. Smith EJ, Muller CL, Sartorius JA, White DR, Maslow AS. C-reactive protein as a predictor of chorioamnionitis. J Am Osteopath Assoc. 2012; 112 (10): 660-4.

2. Curtin WM, Katzman PJ, Florescue H, Metlay LA. Accuracy of signs of clinical chorioamnionitis in the term parturient. J Perinatol. 2013; 33 (6): 422-8.

3. Winzer C, Wagner O, Festa A, Schneider B, Roden M, Bancher-Todesca D, Pacini G, et al. Plasma adiponectin, insulin sensitivity, and subclinical inflammation in women with prior gestational diabetes mellitus. Diabetes Care 2004; 27 (7): 1721-1727.

4. Wolf M, Sandler L, Hsu K, et al.First-trimester C-reactive protein and subsequent gestational diabetes. Diabetes Care 2003; 26 (3): 819-824.

5. D‘Anna R, Baviera G, De Vivo A, Facciolà G, Di Benedetto A, Corrado F. C-Reactive Protein as an Early Predictor of Gestational Diabetes Mellitus J Reprod Med 2006; 51:55-58.

6. Retnakaran R, Hanley AJ, Raif N, Connelly PW, Sermer M, Zinman B. Creactive protein and gestational diabetes: The central role of maternal obesity. JCEM 2003; 88 (8): 3507-3512.

7. Howman RA, Charles AK, Jacques A, Doherty DA, Simmer K, Strunk T, et al. Inflamatory and Haematological Markers in the Maternal, Umbilical Cord and Infant Circulation in Histological Chorioamnionitis. Plos One 2012; 7 (12): e51836. doi:10.1371/ journal.pone.0051836

8. Shim SS, Romero R, Hong JS, Park CW, Jun JK, et al. Clinical significance of intra-amniotic inflammation in patients with preterm premature rupture of membranes. Am J Obstet Gynecol 2004: 191: 1339-1345

9. Molano M, Van den Brule A, Plummer M, Weiderpass E, Posso H, Arsian A, et al. Determinantion of clearance of Human Papillomavirus Infection in Colombian Women with normal cytology: A population-based, 5-year follow-up study. Am J Epidemiol 2003;158:486.

10. Reich O, Ballon M. DNA cytometry as a first line method for diagnosis of cervical with respect to clinical behavior. Eur J Gynaecol Oncol 2010;4:372.

11. Yoon JH, Yoo SC, Kim WY, Chang SJ, Chang KH, Ryu HS. Role of HPV DNA testing for detection of High grade cervical lesions in women with atypical squamous cells of undetermined significance: A prospective study in Korean population. Eur J Gynaecol Oncol 2009;3:271.

Coresponding author: Mr sci. med. dr Aleksandra Tubic Adress: Zelengorska 19/16, 18000 Nis, Serbia e-mail: ackana@medianis.net 